\title{
How may a shift towards a more sustainable food consumption pattern affect nutrient intakes of Dutch children?
}

\author{
Elisabeth HM Temme, ${ }^{*}$, Helena ME Bakker, S Marije Seves, Janneke Verkaik-Kloosterman, \\ Arnold L Dekkers, Joop MA van Raaij and Marga C Ocké \\ National Institute for Public Health and the Environment (RIVM), PO Box 1, 3720 BA Bilthoven, The Netherlands
}

Submitted 3 July 2015: Accepted 13 July 2015

\begin{abstract}
Objective: Food has a considerable environmental impact. Diets with less meat and dairy reduce environmental impact but may pose nutritional challenges for children. The current modelling study investigates the impact of diets with less or no meat and dairy products on nutrient intakes.

Design: Energy and nutrient intakes were assessed for observed consumption patterns (reference) and two replacement scenarios with data from the Dutch National Food Consumption Survey - Young Children (2005-2006). In the replacement scenarios, $30 \%$ or $100 \%$ of the consumed dairy and meat (in grams) was replaced by plant-derived foods with similar use.

Setting: The Netherlands.

Subjects: Children ( $n$ 1279) aged 2-6 years.

Results: Partial and full replacement of meat and dairy foods by plant-derived foods reduced SFA intake by $9 \%$ and $26 \%$, respectively, while fibre intake was $8 \%$ and $29 \%$ higher. With partial replacement, micronutrient intakes were similar, except for lower vitamin $\mathrm{B}_{12}$ intake. After full meat and dairy replacement, mean intakes of $\mathrm{Ca}, \mathrm{Zn}$ and thiamin decreased by $5-13 \%$, and vitamin $\mathrm{B}_{12}$ intake by $49 \%$, while total intake of Fe was higher but of lower bioavailability. With full replacement, the proportion of girls aged 4-6 years with intakes below recommendations was $15 \%$ for thiamin, $10 \%$ for vitamin $\mathrm{B}_{12}$ and $6 \%$ for $\mathrm{Zn}$.

Conclusions: Partial replacement of meat and dairy by plant-derived foods is beneficial for children's health by lowering SFA intake, increasing fibre content and maintaining similar micronutrient intakes. When full replacements are made, attention is recommended to ensure adequate thiamin, vitamin $\mathrm{B}_{12}$ and $\mathrm{Zn}$ intakes.
\end{abstract}

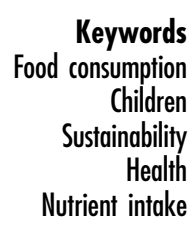

The limited resources on our planet pose challenges for future food supply and food consumption patterns ${ }^{(1,2)}$. Typically, $20-30 \%$ of the environmental impact of final household consumption relates to food, and meat and dairy have a particularly large share ${ }^{(3)}$. To lower the burden of human consumption on the environment, consumption patterns need to change from a diet rich in animal foods to one with a larger share of plant-based foods. Such a diet is closer to health guidelines and more environmentally friendly than currently consumed diets ${ }^{(4)}$. The shift may also benefit human health ${ }^{(5-7)}$. This gives an opportunity to combine sustainability messages with public health messages. The evidence base for what direction current food consumption patterns should change is under development. Dietary patterns need to be identified that provide us the many nutrients in appropriate amounts for our health and which are sustainable ${ }^{(2,8)}$.
The consumption of meat and dairy has a major impact on the environment ${ }^{(2)}$. Modelling studies suggest that public health and climate change dietary goals are in broad alignment when the consumption of meat and dairy products is reduced ${ }^{(9)}$. A scenario with $50 \%$ reduction in meat and dairy replaced by fruit, vegetables and cereals has the largest impact on deaths from CHD, stroke and cancer $^{(9)}$. Reduction of the current high consumption of meat and dairy and/or replacement by plant-based substitutes is therefore an option for change. Plant-based substitutes provide mostly a more environmentally friendly alternative ${ }^{(5,10,11)}$. A reduction of meat and dairy consumption could benefit health by lowering the intake of SFA and, when replaced by plant foods, increasing fibre intake $^{(9,12)}$. Due to the role of meat or dairy as supplier of essential vitamins and minerals in currently observed $\operatorname{diets}^{(13,14)}$, nutritional challenges are foreseen for $\mathrm{Ca}, \mathrm{Fe}$, 
$\mathrm{Zn}$, riboflavin and vitamin $\mathrm{B}_{12}{ }^{(13)}$. This may be especially important for children because of growth requirements. To our knowledge, the shift in (micro) nutrient intakes from an animal-based towards a plant-based diet has not been quantified for children.

The objective of the present study was to model the impact of more sustainable diets with less or no meat and dairy products on nutrient intakes in young Dutch children. Meat and dairy foods were replaced by plantbased foods. Habitual intakes of energy, SFA, protein, fibre, $\mathrm{Ca}, \mathrm{Fe}, \mathrm{Zn}$, thiamin and vitamin $\mathrm{B}_{12}$ were evaluated for a reference as well as a 'less meat and dairy' and a 'no meat and dairy' scenario.

\section{Materials and methods}

\section{Data on food consumption, nutrient composition and environmental impact}

Data from the Dutch National Food Consumption Survey (DNFCS) - Young Children (2005-2006) ${ }^{(15)}$ were used to estimate total nutrient intakes for the reference scenario (baseline consumption). This survey is the most recent food consumption survey in the Netherlands for children aged 2-6 years. Briefly, parents/caretakers of 1279 children recorded food consumption with a food record on two non-consecutive days (all days of the week were represented equally) and filled in a general questionnaire including questions on dietary supplement use.

For the evaluation of environmental impact, two environmental indicators were chosen: (i) greenhouse gas emissions (GHGE), i.e. $\mathrm{kg} \mathrm{CO}_{2}$-equivalents $\left(\mathrm{CO}_{2} \mathrm{e}\right) /$ person per d; and (ii) land use of foods consumed, i.e. $\mathrm{m}^{2}$.year/ person per $\mathrm{d}$. Data for these parameters for meat, dairy and replacement products were derived from existing publications of Blonk Consultants, an independent advisory body on the environment ${ }^{(16)}$. Existing data are calculated in life-cycle assessments and include all stages from farm to fork.

\section{Replacement scenarios}

The impact of replacement was evaluated comparing two replacement scenarios with the reference scenario: the 'less meat and dairy' and the 'no meat and dairy' scenario. In the 'less meat and dairy' scenario, 30\% of meat and dairy consumption (cheese and milk products) was replaced by plant-derived substitutes. In the 'no meat and dairy' scenario, all meat and dairy consumed was replaced by plant-derived substitutes. Meat and dairy foods were defined as foods fully or predominantly consisting of meat or dairy. Replacement foods needed to be more ecologically sustainable (taking land use and $\mathrm{CO}_{2} \mathrm{e}$ as indicators) than meat and dairy ${ }^{(16)}$. For all foods, the amount (in grams) of the originally consumed food was replaced by exactly the same amount of replacement food.

To evaluate a replacement of meat and dairy by plantderived products while staying close to the current eating habits, eligible replacement foods were foods with similar use in terms of the moment of consumption (breakfast, lunch, dinner and between meals). For example, cheese consumed as a snack in the evening was not replaced by a sandwich filling, but by a plant-derived snack. The top three most-consumed plant-derived replacement food groups were chosen from the Dutch Food Composition Database ${ }^{(17)}$. Meats consumed at dinner were replaced by a variety of plant-derived meat substitutes (soya foods, $28 \%$ (twice weekly); vegetarian meat, 58\% (four times weekly); pulses $14 \%$, (once weekly); see Table 1). This is in line with recommendations for a vegetarian diet ${ }^{(18)}$. Meat or cheese eaten as sandwich fillings was randomly replaced by a variety of plant-derived sandwich fillings; one-third was replaced by savoury (e.g. peanut butter), one-third by sweet (e.g. chocolate sprinkles) and one-third by vegetarian fillings (e.g. vegetarian ham). Dairy foods were replaced by similar soya-based foods, e.g. semiskimmed milk was replaced by soya milk, and milk desserts by soya milk desserts.

For meat consumed at dinner, three categories of substitutes replacing meat at dinner were identified: soya products, vegetarian meat and pulses. For each consumed meat-at-dinner product per person per observed day, a number between 0 and 1 was randomly selected. In the $100 \%$ substitution scenario, if this number fell into the range $0-0 \cdot 280$, a soya product was selected as a substitute. If the number fell into the range $0.281-0.865$ or 0.866-1.000, vegetarian meat and pulses were chosen as a substitute, respectively. In the $30 \%$ substitution scenario, the random numbers $0-0.333$ were used only to allocate substitutes. This means that numbers 0-0.093 were substituted with a soya product, numbers in the range 0.094-0.286 were substituted with vegetarian meat, and numbers $0 \cdot 287-0 \cdot 333$ were substituted with pulses. Within the group 'vegetarian meat and pulses', a further subdivision was made for different food products, again taking into account the current consumption frequency in DNFCS Young Children. The random number allocation was repeated ten times for each scenario. Since the differences in mean nutrient intakes between these replicates were very small $(\mathrm{CV}<1 \%)$, one allocation was randomly chosen to represent that scenario.

For sandwich fillings, a similar procedure was applied with three categories of substitutes: savoury (e.g. peanut butter), sweet (e.g. chocolate sprinkles) and vegetarian fillings (e.g. vegetarian ham). Each category had a onethird chance to be chosen and a subdivision per category was made based on current consumption frequency in DNFCS - Young Children.

\section{Nutritional and environmental impact}

Total intakes, for the reference scenario and the two replacement scenarios, were calculated by the summation of the intakes of all foods consumed per child, per observation day, resulting in observed intakes with intra-individual and 
Table 1 Average daily consumption (frequency and amount) at baseline of the top three most-consumed products consisting of meat or dairy and products used as a substitute, their corresponding nutritional composition per $100 \mathrm{~g}$ of product, and their corresponding environmental impact per $1 \mathrm{~kg}$ of product

\begin{tabular}{|c|c|c|c|c|c|c|c|c|c|c|c|c|c|}
\hline \multicolumn{3}{|c|}{ Consumption at baseline } & \multicolumn{9}{|c|}{ Nutritional composition/100 g } & \multicolumn{2}{|c|}{$\begin{array}{l}\text { Environmental } \\
\text { impact } / \mathrm{kg}\end{array}$} \\
\hline Product & $\begin{array}{l}\text { Frequency of } \\
\text { consumption* }\end{array}$ & $\begin{array}{l}\text { Consumption } \\
\text { (g/d), for } \\
\text { consumers }\end{array}$ & $\begin{array}{l}\text { Energy } \\
(\mathrm{kJ})\end{array}$ & $\begin{array}{l}\text { SFA } \\
(g)\end{array}$ & $\begin{array}{l}\text { Protein } \\
\text { (g) }\end{array}$ & $\begin{array}{l}\text { Fibre } \\
\text { (g) }\end{array}$ & $\begin{array}{c}\mathrm{Ca} \\
(\mathrm{mg})\end{array}$ & $\begin{array}{c}\mathrm{Fe} \\
(\mathrm{mg})\end{array}$ & $\begin{array}{l}\mathrm{Zn} \\
(\mathrm{mg})\end{array}$ & $\begin{array}{l}\text { Thiamin } \\
(\mathrm{mg})\end{array}$ & $\begin{array}{l}\text { Vitamin } \\
\mathrm{B}_{12}(\mu \mathrm{g})\end{array}$ & $\mathrm{m}^{2} \cdot$ year & $\begin{array}{l}\mathrm{kg} \mathrm{CO}_{2} \\
\text { equivalents }\end{array}$ \\
\hline \multicolumn{14}{|l|}{ Meat } \\
\hline Chicken filet & 186 & 35 & 464 & 0.5 & $23 \cdot 3$ & 0.0 & 6 & 0.6 & 0.7 & 0.08 & 0.20 & 6.9 & 4.6 \\
\hline Minced beef & 183 & 39 & 937 & 7.0 & 18.9 & 0.3 & 8 & 2.0 & $4 \cdot 3$ & 0.03 & 1.90 & 23.0 & $19 \cdot 7$ \\
\hline Hamburger & 122 & 62 & 995 & 7.5 & $16 \cdot 8$ & 0.6 & 14 & 1.8 & 3.7 & 0.09 & 1.52 & 7.8 & 12.9 \\
\hline \multicolumn{14}{|l|}{ Dairy } \\
\hline Milk semi-skimmed & 2634 & 156 & 192 & 1.0 & 3.4 & 0.0 & 122 & 0.0 & 0.4 & 0.03 & 0.44 & 0.8 & 1.3 \\
\hline Yoghurt drink & 1154 & 186 & 258 & 0.1 & $2 \cdot 7$ & 0.0 & 97 & 0.0 & 0.2 & 0.02 & 0.19 & 0.7 & 1.0 \\
\hline Buttermilk & 188 & 174 & 130 & 0.1 & 3.0 & 0.0 & 108 & 0.0 & 0.4 & 0.02 & 0.13 & 1.0 & 1.5 \\
\hline \multicolumn{14}{|l|}{ Sandwich fillings } \\
\hline Cheese, gouda, $48+$ & 892 & 20 & 1526 & 20.5 & $22 \cdot 8$ & 0.0 & 815 & 0.2 & 3.5 & 0.01 & 1.97 & 7.6 & $12 \cdot 3$ \\
\hline Sausage luncheon meat & 281 & 12 & 1093 & 12.9 & 12.0 & 0.0 & 460 & 0.1 & 2.4 & 0.14 & 0.60 & $6 \cdot 0$ & 4.5 \\
\hline Cheese spread, $48+$ & 179 & 19 & 1280 & 9.7 & 11.8 & 0.2 & 18 & 1.3 & 1.7 & 0.03 & 0.66 & 7.6 & $12 \cdot 4$ \\
\hline \multicolumn{14}{|l|}{ Substitutes } \\
\hline \multicolumn{14}{|l|}{ Meat substitutes } \\
\hline \multirow{2}{*}{\multicolumn{14}{|c|}{ Soya products }} \\
\hline Tofu & 3 & & & & & & & & & & & & \\
\hline \multicolumn{14}{|l|}{ Vegetarian meat } \\
\hline Minced meat & 5 & 29 & 571 & 0.1 & $19 \cdot 1$ & 5.7 & 0 & $2 \cdot 1$ & 0.0 & 0.13 & 0.26 & $2 \cdot 7$ & $2 \cdot 2$ \\
\hline Hamburger & 4 & 66 & 786 & 1.1 & $17 \cdot 3$ & 3.0 & 0 & $2 \cdot 1$ & 0.0 & 0.13 & 0.26 & $1 \cdot 7$ & 1.5 \\
\hline Quorn pieces, natural & 2 & 19 & 570 & 0.6 & 14.0 & 5.5 & 32 & 0.5 & 5.6 & $0 \cdot 10$ & 0.13 & 0.4 & $2 \cdot 4$ \\
\hline \multicolumn{14}{|l|}{ Pulses } \\
\hline Beans, white, tomato sauce & 29 & 66 & 380 & 0.1 & $5 \cdot 6$ & $5 \cdot 2$ & 58 & 1.8 & 0.6 & 0.06 & 0.00 & $2 \cdot 7$ & 1.5 \\
\hline Beans, brown, canned & 25 & 50 & 466 & 0.1 & $7 \cdot 1$ & 7.6 & 39 & 1.5 & 0.6 & 0.06 & 0.00 & $2 \cdot 7$ & 1.5 \\
\hline Marrowfats, canned & 6 & 116 & 432 & 0.1 & $6 \cdot 9$ & 6.6 & 35 & 1.0 & 0.7 & 0.09 & 0.00 & $2 \cdot 7$ & 1.5 \\
\hline \multicolumn{14}{|l|}{ Dairy substitutes } \\
\hline Soya milk, high $\mathrm{Ca}$ & 25 & 219 & 197 & 0.3 & 3.7 & 0.6 & 120 & 0.3 & 0.3 & 0.02 & 0.00 & 0.5 & 0.4 \\
\hline Soya milk, diverse flavours & 20 & 169 & 308 & 0.4 & 3.6 & 0.8 & 120 & 0.5 & 0.3 & 0.02 & 0.15 & 0.5 & 0.4 \\
\hline Soya dessert, fruit/vanilla & 1 & 125 & 311 & 0.3 & 3.6 & 1.1 & 120 & 0.3 & - & 0.02 & 0.38 & 0.5 & 0.4 \\
\hline \multirow{2}{*}{\multicolumn{14}{|c|}{ Filling substitutes }} \\
\hline \multicolumn{13}{|l|}{ Savoury fillings } & \\
\hline Peanut butter & 532 & 21 & 2742 & $10 \cdot 4$ & 21.9 & $5 \cdot 0$ & 50 & 1.4 & $2 \cdot 3$ & 0.10 & 0.00 & $5 \cdot 1$ & 1.7 \\
\hline Sandwich spread, natural & 12 & 17 & 951 & $2 \cdot 3$ & 1.4 & 0.6 & 56 & $2 \cdot 0$ & - & 0.00 & - & 1.5 & 0.7 \\
\hline \multicolumn{14}{|l|}{ Sweet fillings } \\
\hline Chocolate nut spread & 627 & 22 & 2338 & $9 \cdot 3$ & 5.7 & 3.0 & 116 & 4.5 & 1.3 & 0.03 & 0.00 & 1.7 & $2 \cdot 2$ \\
\hline Sprinkles, milk chocolate & 382 & 9 & 1919 & 9.4 & $6 \cdot 3$ & 3.7 & 116 & 4.5 & 1.1 & 0.05 & 0.52 & 1.7 & $2 \cdot 2$ \\
\hline Sprinkles, fruit & 287 & 8 & 1671 & 0.0 & 0.1 & 0.0 & 1 & 0.1 & 0.0 & 0.00 & 0.00 & 1.7 & $2 \cdot 2$ \\
\hline \multicolumn{14}{|l|}{ Vegetarian fillings } \\
\hline Pâté, vegetarian & 6 & 25 & 1155 & 3.5 & 7.9 & 1.5 & 20 & $2 \cdot 1$ & 0.1 & 0.13 & 0.15 & 2.5 & $2 \cdot 1$ \\
\hline Steak tartare, vegetarian & 2 & 28 & 1398 & 4.0 & $12 \cdot 0$ & 0.0 & 20 & $2 \cdot 1$ & 0.1 & 0.13 & 0.15 & 2.5 & $2 \cdot 1$ \\
\hline Ham, vegetarian & 2 & 16 & 866 & 1.0 & 21.0 & 1.5 & 0 & $2 \cdot 1$ & 0.0 & 0.13 & 0.15 & 2.5 & $2 \cdot 1$ \\
\hline \multicolumn{14}{|l|}{ Snack substitutes $†$} \\
\hline Rice cakes, puffed & 132 & 9 & 1622 & 0.5 & $7 \cdot 2$ & 4.1 & 18 & 0.9 & $2 \cdot 0$ & 0.34 & 0.00 & 2.4 & $2 \cdot 0$ \\
\hline
\end{tabular}

- indicates not present in NEVO-Tabel 2011 ${ }^{(17)}$.

*The number of times the food was consumed during the 2558 interview days of 1279 children.

†Snacks consumed after dinner (food consumption code 11).

inter-individual variances. For environmental impact, the summation was restricted to meat and dairy and their plantbased replacement foods. In the tables, mean intakes are reported unless otherwise stated. Results are presented in age-gender groups (girls aged 2-3 years and 4-6 years; boys aged 2-3 years and 4-6 years).

To evaluate whether intakes are adequate on a population level, it is generally considered appropriate to use the Estimated Average Requirement $(\mathrm{EAR})^{(19)}$. The EAR cut-point method estimates the prevalence of inadequate intakes as the proportion of the population with usual intakes below the EAR. The EAR is defined as the intake adequate for $50 \%$ of the population. The use of this technique is based on a number of assumptions: (i) intakes and requirements for the nutrient must be independent; (ii) the distribution of requirements must be symmetric around its mean, the EAR; and (iii) the variance of the distribution of requirements should be smaller than the variance of the usual intake distribution ${ }^{(19)}$. The EAR cut-point method is valid for all nutrients presented in the current paper except for fibre and SFA. The EAR was also appropriate for $\mathrm{Fe}$ as the Box-Cox transformation resulted in a normal distribution. SFA and $\mathrm{Zn}$ intakes were evaluated via the Tolerable Upper Intake Level (UL). For fibre intake, the Adequate Intake (AI) was available, which allows a qualitative evaluation about the adequacy. For median intakes at or above the $\mathrm{AI}$, the prevalence of inadequate intake is considered low ${ }^{(15,20)}$. The reference values were obtained primarily from the dietary reference values of the Health Council of the Netherlands (for SFA, protein ${ }^{(21)}$ ) and the Institute of Medicine (for $\mathrm{Ca}^{(22)}$, thiamin and vitamin $\mathrm{B}_{12}{ }^{(23)}$ and $\left.\mathrm{Fe}, \mathrm{Zn}^{(24)}\right)$ as well as from the 
European Food Safety Authority (for fibre ${ }^{(25)}$ and upper limits for $\mathrm{Zn}^{(26)}$ ). The Health Council of the Netherlands established an $\mathrm{AI}$ for $\mathrm{Ca}$, thiamin ${ }^{(27)}$, vitamin $\mathrm{B}_{12}{ }^{(28)}$, Fe and $\mathrm{Zn}^{(29)}$. The Institute of Medicine established an EAR for these nutrients; therefore, we decided to use these dietary reference intakes in our study.

\section{Statistical methods}

Dietary reference intakes are generally related to health effects associated with chronically too-low intakes. Therefore, the long-term intake, also called the habitual or usual intake, is of interest rather than the acute dietary exposure. In the DNFCS food consumption is measured in the short term with repeated $24 \mathrm{~h}$ food records. Such data include, besides the inter-individual variation, intraindividual variation (day-to-day variation) and as a consequence the intake distribution is wider and proportions of the population below cut-points are overestimated. To overcome this, the habitual intakes of macro- and micronutrients (energy $(\mathrm{kJ} / \mathrm{d})$, SFA (percentage of daily energy intake (E\%)), protein $(\mathrm{g} / \mathrm{d})$, fibre $(\mathrm{g} / \mathrm{d}), \mathrm{Ca}(\mathrm{mg} / \mathrm{d}), \mathrm{Fe}(\mathrm{mg} /$ $\mathrm{d}), \mathrm{Zn}(\mathrm{mg} / \mathrm{d})$, thiamin $(\mathrm{mg} / \mathrm{d})$ and vitamin $\left.\mathrm{B}_{12}(\mu \mathrm{g} / \mathrm{d})\right)$ were estimated by statistical correction for the intraindividual variation using SPADE (Statistical Program to Assess Dietary Exposure) ${ }^{(30)}$. The habitual intake distributions were modelled as a function of age separately for boys and girls. The habitual intake was estimated separately for intake from food (separately for users and non-users of dietary supplements) and intake from dietary supplements and thereafter combined to get the estimate of the total nutrient intake ${ }^{(30)}$. The population's habitual total nutrient intake distributions were compared with dietary reference intakes, and the proportion of inadequate nutrient intakes was calculated in the reference and in the two replacement scenarios. The $95 \%$ confidence bounds were estimated using the bootstrap method with 1000 iterations. Significant differences between scenarios were evaluated by non-overlapping $95 \%$ CI. The results were weighted for small deviances in sociodemographic characteristics, days of the week and season of data collection, in order to give results that are representative for the Dutch children in the Netherlands in 2006 and representative for all days of the week and all seasons. Unless stated otherwise, the statistical software package SAS version $9 \cdot 1 \cdot 3$ was used for modelling.

\section{Results}

\section{Food consumption and composition}

Table 1 shows the consumption, composition and environmental impact of selected meat and dairy foods and their replacements. The upper half of Table 1 shows the average daily consumption (person-days of consumption and amount consumed on consumption days) of the top three most-consumed meat and dairy foods. The lower part of Table 1 shows the top three most-consumed plantderived substitutes used as replacers in the present study, as well as the frequency of consumption and their average daily consumption for consumers at reference. Vegetarian meat and other plant-derived substitutes are rarely consumed in the reference scenario. The replacement sandwich fillings such as peanut butter and chocolate nut spread are consumed frequently by these children. Meat and dairy and plant-based imitation replacement foods (e.g. vegetarian meat and soya dairy substitutes) contain similar amounts of energy, protein and thiamin. Most of the commercially available meat or dairy substitutes are supplemented with $\mathrm{Fe}$, vitamin $\mathrm{B}_{12}$ (for meat replacers such as GoodBite ${ }^{\circledR}$, Vivera ${ }^{\circledR}$ and Tivall products $\left.{ }^{\circledR}\right)^{(31)}$ and $\mathrm{Ca}$ (for dairy replacers) ${ }^{(32)}$. Pulses contain less protein than meat. The SFA and $\mathrm{Zn}$ contents are higher in meat, meat products and cheese compared with replacement foods. On the other hand, fibre content was higher in vegetarian meat and pulses than in meat products and cheese. Plant-derived foods have a similar Fe content compared with meat. However, Fe bioavailability in plant-derived products is lower than in animal-derived products ${ }^{(33)}$.

\section{Environmental impact}

The average land use and GHGE were evaluated for meat and dairy consumption and plant-based replacements only. Consequently, the figures do not reflect the impact of total daily diets. Land use and GHGE of meat are higher than of meat substitutes, although the type of meat is important for environmental impact, with a higher impact for beef, followed by pork and lowest for chicken. The environmental impact of $1 \mathrm{~kg}$ of cheese is similar to that of $1 \mathrm{~kg}$ of pork. Dairy milk is about $0.3 \mathrm{~m}^{2} \cdot$ year $/ \mathrm{kg}$ and $0.9 \mathrm{~kg}$ $\mathrm{CO}_{2} \mathrm{e} / \mathrm{kg}$ higher in environmental impact compared with soya milk.

The average land use and GHGE for a child's daily consumption of meat, dairy and plant-based substitutes in the reference situation was $0.82 \mathrm{~m}^{2}$.year and $0.84 \mathrm{~kg} \mathrm{CO}_{2} \mathrm{e}$, respectively. In the 'less meat and dairy' scenario, the land use and GHGE was $0.68 \mathrm{~m}^{2}$.year and $0.67 \mathrm{~kg} \mathrm{CO}_{2} \mathrm{e}$, respectively, per child per $\mathrm{d}$. When all meat and dairy consumptions were replaced, the land use was reduced to $0.46 \mathrm{~m}^{2}$.year and GHGE to $0.36 \mathrm{~kg} \mathrm{CO}_{2} \mathrm{e}$ per child per $\mathrm{d}$, both compared with the reference situation.

\section{Habitual macronutrient intakes and comparison with requirements}

Table 2 shows the mean intakes of energy and various macronutrients (SFA, protein and fibre) of the reference and the two replacement scenarios. Figure 1 shows the average percentage change in macro- and micronutrient intakes for the 'less meat and dairy' and the 'no meat and dairy scenario' compared with the reference. In general, daily energy and nutrient intakes increased with age, and intakes were higher for boys than for girls. In the reference 
Table 2 Habitual mean intakes (and $95 \% \mathrm{Cl}$ ) of macronutrients (energy (kJ/d), SFA (E\%), protein $(\mathrm{g} / \mathrm{d})$ and fibre $(\mathrm{g} / \mathrm{d})$ ) in different meat and dairy replacement scenarios for 1279 Dutch children aged 2-6 years, weighted for sociodemographic factors and season

\begin{tabular}{|c|c|c|c|c|c|c|c|c|c|c|c|c|c|c|}
\hline \multirow[b]{3}{*}{$\begin{array}{l}\text { Age-gender } \\
\text { category }\end{array}$} & \multirow[b]{3}{*}{$n$} & \multirow[b]{3}{*}{ Rec. } & \multirow[b]{3}{*}{ Mean } & \multicolumn{3}{|c|}{ Reference (no replacement) } & \multicolumn{4}{|c|}{ Less meat and dairy $\left(30 \%\right.$ replacement $\left.{ }^{\star}\right)$} & \multicolumn{4}{|c|}{ No meat and dairy $\left(100 \%\right.$ replacement $\left.^{\star}\right)$} \\
\hline & & & & \multicolumn{2}{|c|}{$95 \% \mathrm{Cl}$} & \multirow[b]{2}{*}{$\begin{array}{c}\text { Evaluation } \\
\text { compared with Rec. }\end{array}$} & \multirow[b]{2}{*}{ Mean } & \multicolumn{2}{|c|}{$95 \% \mathrm{Cl}$} & \multirow[b]{2}{*}{$\begin{array}{c}\text { Evaluation } \\
\text { compared with Rec. }\end{array}$} & \multirow[b]{2}{*}{ Mean } & \multicolumn{2}{|c|}{$95 \% \mathrm{Cl}$} & \multirow[b]{2}{*}{$\begin{array}{c}\text { Evaluation } \\
\text { compared with Rec. }\end{array}$} \\
\hline & & & & $\begin{array}{l}\text { Lower } \\
\text { bound }\end{array}$ & $\begin{array}{l}\text { Upper } \\
\text { bound }\end{array}$ & & & $\begin{array}{l}\text { Lower } \\
\text { bound }\end{array}$ & $\begin{array}{l}\text { Upper } \\
\text { bound }\end{array}$ & & & $\begin{array}{l}\text { Lower } \\
\text { bound }\end{array}$ & $\begin{array}{l}\text { Upper } \\
\text { bound }\end{array}$ & \\
\hline & & Energy $(\mathrm{kJ} / \mathrm{d})$ & & & & & & & & & & & & \\
\hline Boys $2-3$ years & 327 & - & $5814^{\mathrm{a}}$ & 5670 & 5953 & - & $5804^{\mathrm{a}}$ & 5672 & 5941 & - & $5728^{a}$ & 5585 & 5864 & - \\
\hline Girls $2-3$ years & 313 & - & $5509^{a}$ & 5233 & 5928 & - & $5512^{\mathrm{a}}$ & 5231 & 5955 & - & $5507^{\mathrm{a}}$ & 5217 & 5897 & - \\
\hline Boys $4-6$ years & 327 & - & $6673^{\mathrm{a}}$ & 6544 & 6820 & - & $6685^{\mathrm{a}}$ & 6552 & 6833 & - & $6637^{\mathrm{a}}$ & 6510 & 6786 & - \\
\hline \multirow[t]{2}{*}{ Girls $4-6$ years } & 312 & - & $6373^{\mathrm{a}}$ & 6118 & 6814 & - & $6383^{\mathrm{a}}$ & 6132 & 6830 & - & $6355^{\mathrm{a}}$ & 6084 & 6770 & - \\
\hline & 327 & $\begin{array}{l}\text { SFA (E\%) } \\
15 \text { (UL)t }\end{array}$ & & 11.2 & . & $\%>>_{4} U L$ & & & & $\%>U L$ & & & & $\%>$ UL \\
\hline Girls 2-3 years & 313 & 15 (UL)† & $11.5^{a}$ & 11.1 & $\begin{array}{l}11 \cdot 8 \\
13.2\end{array}$ & $\begin{array}{l}4 \\
2\end{array}$ & $\begin{array}{l}10 \cdot 5^{\mathrm{D}} \\
10 \cdot 3^{\mathrm{b}}\end{array}$ & $\begin{array}{l}10 \cdot 3 \\
10 \cdot 1\end{array}$ & $\begin{array}{l}10 \cdot 8 \\
10 \cdot 6\end{array}$ & $\begin{array}{l}1 \\
0\end{array}$ & $\begin{array}{l}8 \cdot 3^{c} \\
8 \cdot 9^{c}\end{array}$ & $\begin{array}{l}8 \cdot 1 \\
8.6\end{array}$ & $\begin{array}{r}8 \cdot 6 \\
10.2\end{array}$ & $\begin{array}{l}0 \\
0\end{array}$ \\
\hline Boys 4-6 years & 327 & 10 (UL) $\dagger$ & $11.9^{a}$ & 11.6 & $12 \cdot 2$ & 83 & $11.0^{\mathrm{b}}$ & 10.8 & 11.3 & 71 & $8 \cdot 4^{c}$ & $\begin{array}{l}0.0 \\
8.0\end{array}$ & $\begin{array}{r}10.2 \\
9.7\end{array}$ & 21 \\
\hline \multirow[t]{2}{*}{ Girls 4-6 years } & 312 & 10 (UL)† & $12 \cdot 2^{\mathrm{a}}$ & 11.8 & 14.0 & 91 & $11 \cdot 1^{\mathrm{b}}$ & $10 \cdot 9$ & 11.4 & 77 & $9 \cdot 2^{\mathrm{C}}$ & 8.8 & 10.5 & 27 \\
\hline & & Protein $(\mathrm{g} / \mathrm{d})$ & & & & $\%<$ EAR & & & & $\%<$ EAR & & & & $\%<\mathrm{EAR}$ \\
\hline Boys $2-3$ years & 327 & $11(\mathrm{EAR}) \ddagger$ & $46^{\mathrm{a}}$ & 44 & 47 & 0 & $45^{\mathrm{ab}}$ & 43 & 46 & 0 & $42^{b}$ & 41 & 43 & 0 \\
\hline Girls $2-3$ years & 313 & 10 (EAR)‡ & $43^{\mathrm{a}}$ & 42 & 47 & 0 & $42^{\mathrm{a}}$ & 40 & 46 & 0 & $48^{a}$ & 46 & 49 & 0 \\
\hline Boys $4-6$ years & 327 & $17(\mathrm{EAR}) \ddagger$ & $52^{\mathrm{a}}$ & 51 & 54 & 0 & $51^{\mathrm{ab}}$ & 49 & 52 & 0 & $40^{\mathrm{b}}$ & 38 & 44 & 0 \\
\hline \multirow[t]{2}{*}{ Girls $4-6$ years } & 312 & $16(\mathrm{EAR}) \neq$ & $48^{a}$ & 47 & 52 & 0 & $47^{\mathrm{a}}$ & 45 & 51 & 0 & $44^{\mathrm{a}}$ & 43 & 48 & 0 \\
\hline & & Fibre $(\mathrm{g} / \mathrm{d})$ & $12.9^{a}$ & 12.5 & $13 \cdot 3$ & Adequacyll & $13 \cdot 8^{\mathrm{b}}$ & 13.4 & $14 \cdot 3$ & Adequacyll & $16 \cdot 6^{\mathrm{c}}$ & $16 \cdot 1$ & $17 \cdot 0$ & $\begin{array}{c}\text { Adequacyll } \\
\text { ad }\end{array}$ \\
\hline Girls 2-3 years & $\begin{array}{l}321 \\
313\end{array}$ & $10(\mathrm{Al}) \S$ & $12 \cdot 0^{\mathrm{a}}$ & $\begin{array}{l}12 \cdot 0 \\
11.5\end{array}$ & 12.7 & incl & $\begin{array}{l}13.8 \\
12.9^{\mathrm{ab}}\end{array}$ & $\begin{array}{l}13.4 \\
12 \cdot 3\end{array}$ & $\begin{array}{l}14 \cdot 3 \\
13.6\end{array}$ & $\begin{array}{l}\text { ad } \\
\text { ad }\end{array}$ & $15 \cdot 5^{\mathrm{b}}$ & $\begin{array}{l}10.1 \\
14.9\end{array}$ & $16 \cdot 6$ & $\begin{array}{l}\text { ad } \\
\text { ad }\end{array}$ \\
\hline Boys 4-6 years & 327 & $14(\mathrm{Al}) \S$ & $14 \cdot 2^{\mathrm{a}}$ & 13.8 & 14.7 & $\mathrm{ad}$ & $15 \cdot 3^{\mathrm{b}}$ & 14.8 & $15 \cdot 8$ & $\mathrm{ad}$ & $18 \cdot 3^{c}$ & 17.8 & $18 \cdot 8$ & ad \\
\hline Girls 4-6 years & 312 & $14(\mathrm{Al}) \S$ & $12 \cdot 9^{a}$ & $12 \cdot 3$ & $13 \cdot 7$ & $\mathrm{pa}$ & $13 \cdot 9^{\mathrm{ab}}$ & 13.4 & 14.7 & incl & $16 \cdot 8^{\mathrm{C}}$ & $16 \cdot 2$ & $18 \cdot 0$ & ad \\
\hline
\end{tabular}

Rec., recommendation; E\%, percentage of daily energy intake; UL, Tolerable Upper Intake Level; Al, Adequate Intake; EAR, Estimated Average Requirement.

a,b,c Mean values within a row with unlike superscript letters were significantly different (based on the $95 \% \mathrm{Cl}$ around the mean as estimated using 1000 bootstrap samples).

*Replacement of meat and cheese fillings, meat for dinner, and dairy drinks and desserts by plant-derived substitutes.

TUL for SFA from Health Council of the Netherlands ${ }^{(21)}$.

tEAR for protein from Health Council of the Netherlands ${ }^{(21)}$.

SAl for fibre from EFSA Panel on Dietetic Products and Nutrition and Allergies ${ }^{(25)}$

$\|$ ad = a large proportion of the population has an adequate intake (median intake is above the Al); pa = median intake is below the corresponding Al, incl=inconclusive (within this age group, some ages have a median intake below and some above the Al). 


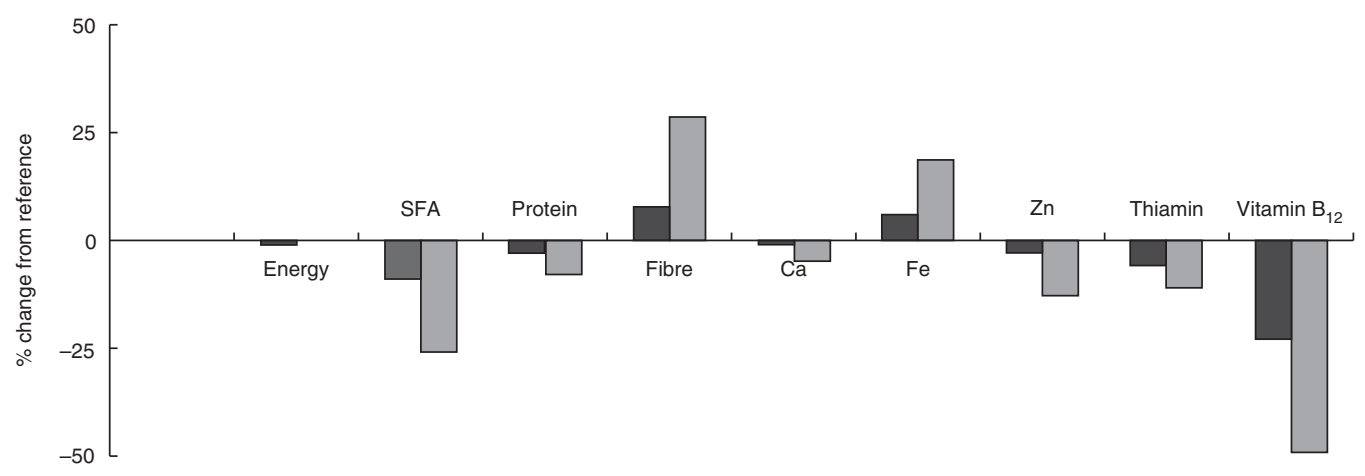

Fig. 1 Percentage change in nutrient intake for the 'less meat and dairy' scenario $(\square)$ and the 'no meat and dairy' scenario ( $\square$ ), compared with the reference, in 1279 Dutch children aged 2-6 years

scenario, the intake of total energy ranged from 5509 to $5814 \mathrm{~kJ} / \mathrm{d}$ for girls and boys aged 2-3 years and from 6373 to $6673 \mathrm{~kJ} / \mathrm{d}$ for girls and boys aged $4-6$ years, respectively. The 'less meat and dairy' and 'no meat and dairy' scenarios did not significantly change the mean energy intake.

In the reference scenario, SFA was 11-12 $\mathrm{E} \%$ in all age-gender groups. The 'less meat and dairy' scenario resulted on average in a $9 \%$ reduction and the 'no meat and dairy' scenario in a $26 \%$ reduction in SFA intake. In the reference scenario, $83-91 \%$ of the 4-6-year-olds had SFA intakes above the UL of $10 \mathrm{E} \%$ as assessed by the Health Council of the Netherlands ${ }^{(21)}$. Replacing meat and dairy with plant-based substitutes resulted in less 4-6-year-old children exceeding the UL. This reduction was $15 \%$ and $72 \%$, respectively, for the 'less meat and dairy' and the 'no meat and dairy' scenario. The proportion of boys and girls aged 2-3 years who exceeded the UL for SFA of $15 \mathrm{E} \%{ }^{(21)}$ in the reference situation was $2-4 \%$, and decreased to $0-1 \%$ in the replacement scenarios.

The average protein intake in the reference scenario was $43-52 \mathrm{~g} / \mathrm{d}$, depending on age and gender. Meat and dairy replacements of $30 \%$ or $100 \%$ decreased the total protein intake on average by $3 \%$ and $8 \%$, respectively. Within all scenarios and all age-gender categories, the proportion of children with a habitual protein intake under the corresponding EAR equalled $0 \%$.

The average habitual intake of fibre within the reference scenario ranged from $12 \cdot 0$ to $14 \cdot 2 \mathrm{~g} / \mathrm{d}$. Girls aged $4-6$ years had the highest risk of an inadequate fibre intake comparing their median intake with the AI. Fibre intake increased significantly by $8 \%$ and $29 \%$ within the 'less meat and dairy' and 'no meat and dairy' groups, respectively. In the 'no meat and dairy' scenario, fibre intakes of all age and gender groups were evaluated as adequate.

\section{Micronutrient intakes from food sources and dietary supplements}

Table 3 shows the mean daily intakes of various micronutrients $\left(\mathrm{Ca}, \mathrm{Fe}, \mathrm{Zn}\right.$, thiamin and vitamin $\left.\mathrm{B}_{12}\right)$ within the reference scenario and the two replacement scenarios.
The daily mean intake of $\mathrm{Ca}$ in the reference scenario ranged from 767 to $798 \mathrm{mg}$ for the four age-gender groups. In the reference as well as both replacement scenarios, $0-80 \%$ of the habitual intakes were under the corresponding EAR of 500 or $800 \mathrm{mg} / \mathrm{d}$ (for 2-3-year-olds and 4-6-year-olds, respectively). The mean daily intake of Fe increased from $6.6-7.7 \mathrm{mg} / \mathrm{d}$ in the reference scenario to $8 \cdot 0-9.1 \mathrm{mg} / \mathrm{d}$ in the 'no meat and dairy' scenario, depending on age and gender. A $30 \%$ replacement of meat and dairy resulted on average in a significant increase of $6 \%$ in $\mathrm{Fe}$ intake, but $\mathrm{Fe}$ was of lower bioavailability. For the reference scenario, the mean $\mathrm{Zn}$ intake was 5-6 mg/d in all age-gender groups. Zn intake reduced especially in the 'no meat and dairy' scenario by $13 \%$. The proportion of children with $\mathrm{Zn}$ intakes exceeding the UL decreased with meat and dairy replacement. When a replacement of $100 \%$ in meat and dairy was accomplished, almost none of the children aged 2-6 years had habitual $\mathrm{Zn}$ intakes above the UL, while $6 \%$ of the girls aged 4-6 years had $\mathrm{Zn}$ intakes below the corresponding EAR.

For the reference scenario, thiamin intake was $0.83-$ $0.94 \mathrm{mg} / \mathrm{d}$ in all age-gender groups. The proportion of girls aged 4-6 years with an intake below the corresponding EAR was $2 \%$. Among girls between the ages of 4 and 6 years, a meat and dairy replacement of $100 \%$ decreased the average daily intake of thiamin by $11 \%$ compared with the reference scenario. This decrease resulted in a larger proportion (15\%) of girls aged 4-6 years with an intake below the corresponding EAR. Also in the other age-gender groups, the 'no meat and dairy' scenario resulted in more (2-6\%) children with thiamin intakes under the EAR.

In the reference scenario, the mean daily total vitamin $\mathrm{B}_{12}$ intake ranged from $2 \cdot 7$ to $3.0 \mu \mathrm{g}$ for the four agegender groups. A significant decrease of on average $23 \%$ and $49 \%$ in daily vitamin $\mathrm{B}_{12}$ intake was calculated in the 'less meat and dairy' and 'no meat and dairy' scenario, respectively. In the 'no meat and dairy' scenario, $0-10 \%$ of the children had a habitual vitamin $\mathrm{B}_{12}$ intake below the corresponding EAR. 
Table 3 Habitual mean intakes $\left(95 \% \mathrm{Cl}\right.$ ) of micronutrients (calcium $(\mathrm{mg} / \mathrm{d})$, iron $(\mathrm{mg} / \mathrm{d})$, zinc $(\mathrm{mg} / \mathrm{d})$, thiamin $(\mathrm{mg} / \mathrm{d})$ and vitamin $\left.\mathrm{B}_{12}(\mu \mathrm{g} / \mathrm{d})\right)$ from food sources and dietary supplements in different meat and dairy replacement scenarios for 1279 Dutch children aged 2-6 years, weighted for sociodemographic factors and season

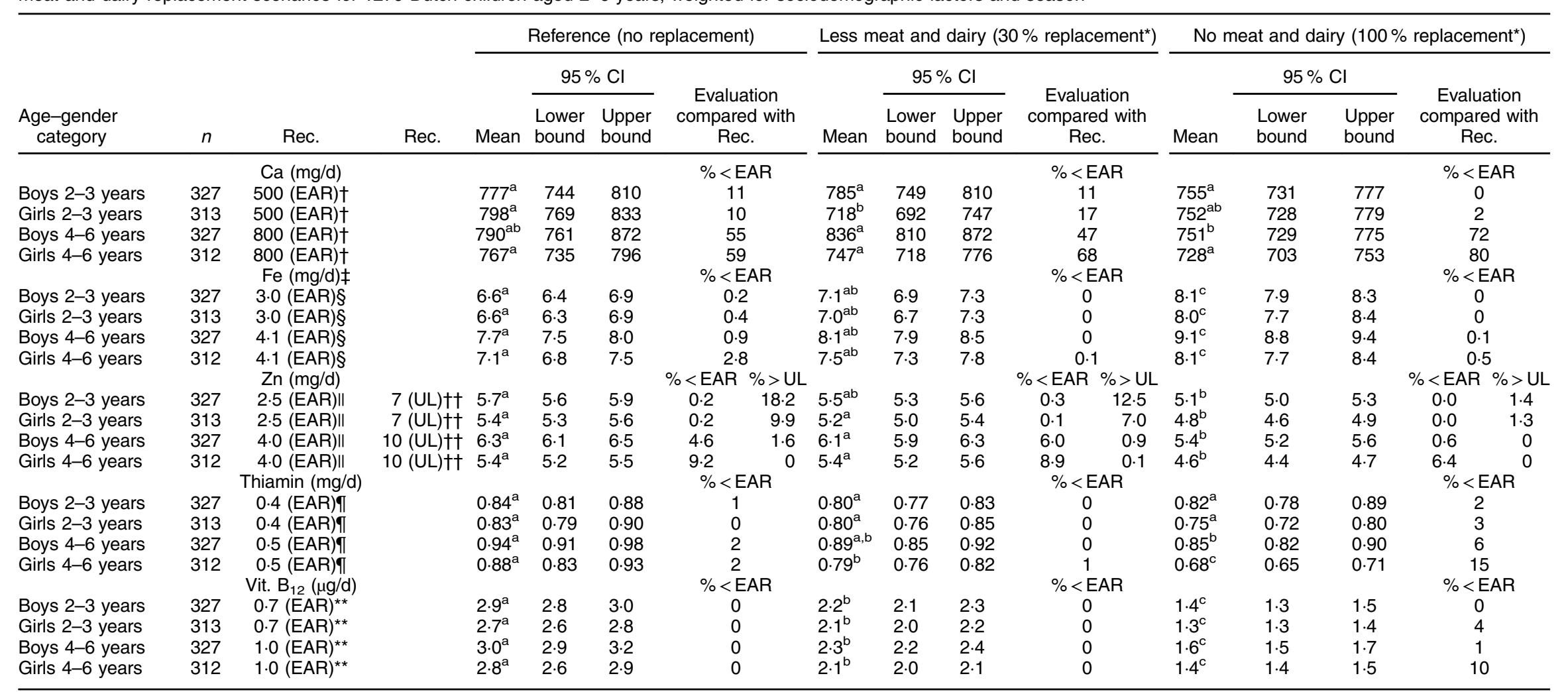

Rec., recommendation; UL, Tolerable Upper Intake Level; EAR, Estimated Average Requirement.

a,b,c Mean values within a row with unlike superscript letters were significantly different (based on the $95 \% \mathrm{Cl}$ around the mean as estimated using 1000 bootstrap samples). *Replacement of meat and cheese fillings, meat for dinner, and dairy drinks and desserts by plant-derived substitutes.

fFe intake was estimated without taking into account difference in bioavailability between animal and plant sources.

SEAR for Fe from Institute of Medicine

EAR for thiamin from Institute of Medine

(23)

t+UL for Zn from EFSA Scientific Committee on Food and Scientific Panel on Dietetic Products Nutrition and Allergies ${ }^{(26)}$. 


\section{Discussion}

Shifting towards a more environmentally friendly food consumption pattern helps protect the limited resources of our planet ${ }^{(34)}$. In the present study, the replacement of meat and dairy consumption (30\% or $100 \%$ ) by plantderived foods was evaluated especially for its impact on the nutrient intakes of children.

In short, we found from our scenario study that partial and full replacement of meat and dairy foods by plantderived foods resulted in a reduced SFA intake of $9 \%$ and $26 \%$, respectively, while fibre intake was $8 \%$ and $29 \%$ higher. After $100 \%$ meat and dairy replacement by plant foods, mean intakes of $\mathrm{Ca}, \mathrm{Zn}$ and thiamin decreased by $5-13 \%$, and vitamin $B_{12}$ intake by $49 \%$, while total intake of Fe was higher but of lower bioavailability. Diets with less meat and dairy were in line with recommendations except for SFA, Ca (all age and gender categories) and $\mathrm{Zn}$. SFA (for boys and girls aged 4-6 years) was above and Ca intake (all age and gender categories) was below recommendations in both replacement scenarios as well as in the reference scenario. In girls aged 4-6 years, the full meat and dairy replacement scenario resulted in 6\%,10\% and $15 \%$ of children with inadequate intakes for $\mathrm{Zn}$, vitamin $\mathrm{B}_{12}$ and thiamin, respectively.

While the benefits for the planet are evident from the reduced land use and GHGE, and for child health from the lower SFA and higher fibre intakes, there is a risk of toolow thiamin, vitamin $\mathrm{B}_{12}$ and $\mathrm{Zn}$ intakes. With the 'less meat and dairy' scenario, the intakes are similar compared with the reference situation. With the 'no meat and dairy' scenario, the proportion of girls aged 4-6 years with intakes below EAR increased, up to $15 \%$ for thiamin, $10 \%$ for vitamin $\mathrm{B}_{12}$ and $6 \%$ for $\mathrm{Zn}$.

Given the critical role of $\mathrm{Zn}$ in normal growth and development and immune function, the fact that dietary $\mathrm{Zn}$ fell below the EAR should not be disregarded. $\mathrm{Zn}$ deficiency has been reported in diverse populations and age groups, even in Western populations ${ }^{(35)}$. Recent studies on current intakes of European children indicate considerable variation in $\mathrm{Zn}$ intake, especially in young girls ${ }^{(36)}$. In the USA, children consume recommended amounts of $\mathrm{Zn}$ according to two national surveys, the 1988-1991 National Health and Nutrition Examination Survey (NHANES III) ${ }^{(37)}$ and the 1994 Continuing Survey of Food Intakes of Individuals (CSFII) ${ }^{(38)}$. In addition, the Feeding Infants and Toddlers Study (FITS) 2008 showed that the usual intakes of B-vitamins, bone-related nutrients and other micronutrients were adequate relative to the EAR, except for $\mathrm{Zn}$ and $\mathrm{Fe}$ and in a small subset of older infants ${ }^{(39)}$. On the other hand, thiamin deficiency is rare in industrialised countries. Our study shows that full replacement of meat and dairy may increase the proportion of inadequate intakes. $\mathrm{Zn}$ as well as thiamin intakes may be increased by consuming more wholegrain foods (such as bread), pulses and legumes ${ }^{(40)}$. Furthermore, processing techniques can enhance the bioavailability of $\mathrm{Zn}$ because leavening partially breaks down the phytate $^{(40)}$.

Vitamin $B_{12}$ intakes lowered substantially by $49 \%$, with the habitual intakes of $10 \%$ of the girls aged 4-6 years falling below the requirements in the 'no meat and dairy' scenario. Data on the adequacy of vitamin $\mathrm{B}_{12}$ intakes and status in children are limited. A recent study showed adequate daily vitamin $\mathrm{B}_{12}$ intakes and status in a representative sample of Canadian children ${ }^{(41)}$. Vegetarians are at risk for vitamin $\mathrm{B}_{12}$ deficiency due to suboptimal intake of vitamin $\mathrm{B}_{12}$ via animal-based foods. Pawlak et al. ${ }^{(42)}$ reported that up to $55 \%$ of vegetarian US children had a too-low vitamin $\mathrm{B}_{12}$ status with higher rates of deficiency reported for children following the vegetarian diet for a longer time.

Challenges were also foreseen for Ca because of the replacement of milk and cheese and for Fe intake because of the replacement of meat ${ }^{(13)}$. With the full meat and dairy replacement, however, estimated $\mathrm{Ca}$ intake was similar and total Fe intake was even slightly higher compared with the reference. Especially the commercial meat and dairy replacements contain approximately a similar amount of $\mathrm{Ca}$ and Fe compared with the foods eaten at reference because they are often enriched. Fe needs further consideration because in the replacement scenarios the majority is from non-haem Fe. Total Fe intake was above the EAR in all scenarios. Non-haem Fe absorption is lower for those consuming vegetarian diets than for those eating non-vegetarian diets. The Institute of Medicine therefore suggested that the Fe requirement for those consuming a vegetarian diet is approximately twofold greater than for those consuming a non-vegetarian $\operatorname{diet}^{(24)}$. Applying this to our results showed that Fe intakes in the 'less meat and dairy' and 'no meat and dairy' scenarios are in line with this recommendation. Advice from the UK focuses on total Fe intake via a healthy balanced diet that includes a variety of foods containing Fe and which should be able to keep Fe intake adequate ${ }^{(43)}$.

For the intakes of SFA and fibre a favourable shift was noted when replacing meat and dairy with plant-based foods. Their replacement by plant-based foods lowered SFA intake by $9 \%$ and $26 \%$ and increased fibre intake by $8 \%$ and $29 \%$ in the 'less meat and dairy' and 'no meat and dairy' replacement scenarios, respectively. With maximal replacement, the majority of Dutch children would be in line with recommendations for SFA as well as for fibre intake. This is expected to be beneficial for children's health. In the long term, diets low in SFA and rich in fibre are associated with a reduced risk of CVD, cancer and obesity $^{(44-46)}$, at least when studied in adults. The additional fibre may lead to decreased energy and nutrient intakes. Although a lower energy intake would be positive for many Dutch adults, this may not be the case for the 2-6-year-old period of a child's life, which is a time of rapid growth. Protein intake was sufficient for all scenarios 
and all age-gender categories. Given the variety of plantbased proteins in the replacement scenarios and high levels of daily protein intake compared with recommendations, it is expected that the provision of essential amino acids is sufficient and in balance. However, this aspect was not addressed in the current calculations.

Recently, studies have focused on the environmental aspects of the adoption of healthy diet recommendations. Adopting healthy diet recommendations reduces the environmental (GHGE and land use) impact compared with current dietary patterns ${ }^{(47,48)}$. In all studies, the consumption of meat and dairy has a major impact on the environment $^{(2)}$. As far as we know, the nutritional impact of the proposed reduction of meat and dairy was never studied specifically in children. The first studies in adult populations to assess environmental as well as nutritional aspects of food intake simultaneously and optimising diets appear in scientific journals ${ }^{(5,48-50)}$. In a previous paper we studied the impact of similar replacements in young women on land use, saturated fat and Fe intake ${ }^{(49)}$. We estimated reductions in saturated fat intake while the total Fe intake was similar or increased slightly. Other micronutrients were not assessed in the previous study.

The choice of substitutes and their composition is crucial for the nutritional intake estimations in the different scenarios. This type of study must be recognised for having a signalling function. In the case of a shift of children's diets towards lower intakes of meat and/or dairy, nutritional status analyses are needed to confirm adequacy of intakes of $\mathrm{Zn}$, thiamin, vitamin $\mathrm{B}_{12}$ and probably Fe by the true prevalence of marginal nutritional statuses. Starting from the current consumption patterns of Dutch children, the choice of savoury (e.g. peanut butter), sweet (e.g. chocolate sprinkles) and vegetarian fillings (e.g. vegetarian ham) as replacements for meat or cheese sandwich fillings seems reasonable. The palatability of the replacement foods and the likelihood of their acceptance by young children play a role in eating behaviour and acceptability of certain replacement foods. Savoury (especially peanut butter) and sweet (e.g. chocolate sprinkles) sandwich fillings were consumed frequently in the reference scenario and children are predisposed to prefer sweet tastes ${ }^{(51)}$. We replaced meat and dairy with equal weights of the replacement foods. This is realistic for vegetarian meat substitutes and dairy replacers from the point of view of foods with similar use. In the Netherlands, pulses and legumes are not frequently eaten as a meat substitute. More common is to eat pulses like a staple food or as a vegetable. This might explain the relatively high consumed quantity (for consumers). Incorporating pulses in the menu as a main component with no meat added will require adapted food habits. For the scenarios, recent guidelines for ecologically friendly dietary patterns ${ }^{(18,52,53)}$ were considered and substitution foods were chosen that were consumed in similar consumption occasions in the reference situation. From a cultural perspective, expecting the Dutch child population to replace all its meat and dairy consumption seems unrealistic. In this cohort of children, $96 \%$ consumed meat or meat products and $98 \%$ milk and cheese on the interview days ${ }^{(14)}$. There are, on the other hand, more and more semi-vegetarians, which makes the 'less meat and dairy' scenario a more realistic one ${ }^{(54)}$. In the present study, a detailed evaluation of the environmental impact of daily diets was not the purpose. Instead, we relied on existing consensus showing that the environmental impact of meat and dairy products is higher than that of plant products ${ }^{(55)}$. Further studies will more specifically address the issue.

We conclude from the current modelling study that the partial replacement of meat and dairy by plant-derived foods is beneficial for children's health by lowering SFA intake, increasing the fibre content and maintaining similar micronutrient intakes. When full replacements are made, attention is recommended to ensure adequate thiamin, vitamin $\mathrm{B}_{12}$ and $\mathrm{Zn}$ in children's diets.

\section{Acknowledgement}

Acknowledgements: The authors thank Marinka Brosens for her assistance in this research project. Financial support: The present study was funded by the Netherlands Food and Consumer Product Safety Authority. The Netherlands Food and Consumer Product Safety Authority had no role in the design, analysis or writing of this article. Conflict of interest: None. Authorship: E.H.M.T. initiated the study. E.H.M.T., H.M.E.B. and J.V.-K. were involved in data collection, development of scenarios and intake assessments. H.M.E.B. prepared the first draft of the manuscript, which was critically evaluated and refined by E.H.M.T., S.M.S., J.V.-K., A.L.D., J.M.A.v.R. and M.C.O. E.H.M.T. prepared the final draft of the manuscript. All authors participated intellectually in the development of the paper. Ethics of human subject participation: Ethical approval was not required.

\section{References}

1. Rockstrom J, Steffen W, Noone K et al. (2009) A safe operating space for humanity. Nature 461, 472-475.

2. Garnett T (2013) Food sustainability: problems, perspectives and solutions. Proc Nutr Soc 72, 29-39.

3. Tukker A, Goldbohm RA, Koning dA et al. (2011) Environmental impacts of changes to healthier diets in Europe. Ecol Econ 70, 1776-1788.

4. Westhoek H, Lesschen JP, Rood T et al. (2014) Food choices, health and environment: effects of cutting Europe's meat and dairy intake. Glob Environ Change 26, 196-205.

5. Macdiarmid JI, Kyle J, Horgan GW et al. (2012) Sustainable diets for the future: can we contribute to reducing greenhouse gas emissions by eating a healthy diet? Am J Clin Nutr 96, 632-639.

6. McMichael AJ, Powles JW, Butler CD et al. (2007) Food, livestock production, energy, climate change, and health. Lancet 370, 1253-1263. 
7. Tilman D \& Clark M (2014) Global diets link environmental sustainability and human health. Nature 515, 518-522.

8. Riley H \& Buttriss JL (2011) A UK public health perspective: what is a healthy sustainable diet? Nutr Bull 36, 426-431.

9. Scarborough P, Allender S, Clarke D et al. (2012) Modelling the health impact of environmentally sustainable dietary scenarios in the UK. Eur J Clin Nutr 66, 710-715.

10. Carlsson-Kanyama A \& Gonzalez AD (2009) Potential contributions of food consumption patterns to climate change. Am J Clin Nutr 89, issue 5, 1704S-1709S.

11. Baroni L, Cenci L, Tettamanti M et al. (2007) Evaluating the environmental impact of various dietary patterns combined with different food production systems. Eur J Clin Nutr $\mathbf{6 1}$, 279-286.

12. Craig WJ (2009) Health effects of vegan diets. Am J Clin Nutr 89, issue 5, 1627S-1633S.

13. Millward DJ \& Garnett T (2010) Plenary Lecture 3: Food and the planet: nutritional dilemmas of greenhouse gas emission reductions through reduced intakes of meat and dairy foods. Proc Nutr Soc 69, 103-118.

14. Van Rossum CTM, Fransen HP, Verkaik-Kloosterman J et al. (2011) Dutch National Food Consumption Survey 2007-2010. Diet of Children and Adults Aged 7 to 69 Years. Bilthoven: RIVM.

15. Ocké MC, van Rossum CTM, Fransen HP et al. (2008) The Dutch National Food Consumption Survey - Young Children 2005/2006. Bilthoven: National Institute for Public Health and Environment.

16. Blonk $\mathrm{H}$, Ponsioen $\mathrm{T}$, Kool A et al. (2011) The Agri-Footprint Method Methodological LCA Framework, Assumptions and Applied Data. Gouda: Blonk Milieu Advies.

17. Nederlands Voedingsstoffenbestand (2011) NEVO-Tabel. The Hague: RIVM/Voedingscentrum.

18. Dutch Nutrition Centre (2011) Hoe eet ik gevarieerd vegetarisch? http://www.voedingscentrum.nl/nl/schijf-van-vijf/ eet-gevarieerd/vegetarisch-eten.aspx (accessed September 2011).

19. Carriquiry AL (1999) Assessing the prevalence of nutrient inadequacy. Public Health Nutr 2, 23-33.

20. Institute of Medicine (2000) Dietary Reference Intakes: Applications in Dietary Assessment. Washington, DC: National Academy Press.

21. Health Council of the Netherlands (2001) Dietary Reference Intakes: Energy, Proteins, Fats, and Digestible Carbobydrates. The Hague: Health Council of the Netherlands.

22. Institute of Medicine (2011) Dietary Reference Intakes for Calcium and Vitamin D. Washington, DC: National Academies Press.

23. Institute of Medicine (1998) Dietary Reference Intakes for Thiamin, Riboflavin, Niacin, Vitamin $B_{6}$, Folate, Vitamin $B_{12}$, Pantothenic Acid, Biotin, and Choline. Washington, DC: National Academy Press.

24. Institute of Medicine (2001) Dietary Reference Intakes for Vitamin A, Vitamin K, Arsenic, Boron, Chromium, Copper, Iodine, Iron, Manganese, Molybdenum, Nickel, Silicon, Vanadium, and Zinc. Washington, DC: National Academy Press.

25. EFSA Panel on Dietetic Products and Nutrition and Allergies (2010) Scientific opinion on dietary reference values for carbohydrates and dietary fibre. EFSA J 8, 1462.

26. EFSA Scientific Committee on Food \& Scientific Panel on Dietetic Products Nutrition and Allergies (2006) Tolerable Upper Intake Levels for Vitamins and Minerals. Parma: EFSA.

27. Health Council of the Netherlands (2000) Dietary Reference Intakes: Calcium, Vitamin D, Thiamin, Riboflavin, Miacin, Pantothenic Acid, and Biotin. The Hague: Health Council of the Netherlands.
28. Health Council of the Netherlands (2003) Dietary Reference Intakes: Vitamin $B_{6}$, Folic Acid and Vitamin $B_{12}$. The Hague: Health Council of the Netherlands.

29. Health Council of the Netherlands (1989) Dietary Reference Values in the Netherlands. The Hague: Health Council of the Netherlands.

30. Dekkers AL, Verkaik-Kloosterman J, van Rossum CT et al. (2014) SPADE, a new statistical program to estimate habitual dietary intake from multiple food sources and dietary supplements. J Nutr 144, 2083-2091.

31. Dutch Nutrition Centre (2014) Vleesvervangers. http:// www.voedingscentrum.nl/encyclopedie/vleesvervangers. aspx (accessed February 2014).

32. Alpro (2014) Het assortiment. Wevelgem. http://www. alpro.com/nl/drinks-naturel (accessed January 2014).

33. Hurrell R \& Egli I (2010) Iron bioavailability and dietary reference values. Am J Clin Nutr 91, issue 5, 1461S-1467S.

34. Freibauer A, Mathijs E, Brunori G et al. (2011) Sustainable Food Consumption and Production in a ResourceConstrained World. Brussels: European Commission, Standing Committee on Agricultural Research.

35. Scientfic Advisory Committee on Nutrition (2008) The Nutritional Wellbeing of the British Population. London: TSO.

36. Mensink GB, Fletcher R, Gurinovic M et al. (2013) Mapping low intake of micronutrients across Europe. Br J Nutr 110, 755-773.

37. Alaimo K, McDowell M, Briefel R et al. (1994) Dietary Intake of Vitamins, Minerals, and Fiber of Persons Ages 2 months and over in the United States: Third National Health and Nutrition Examination Survey, Phase 1, 198691. Hyattsville, MD: National Center for Health Statistics.

38. Interagency Board for Nutrition Monitoring and Related Research (1995) Third Report on Nutrition Monitoring in the United States. Washington, DC: US Government Printing Office.

39. Butte NF, Fox MK, Briefel RR et al. (2010) Nutrient intakes of US infants, toddlers, and preschoolers meet or exceed dietary reference intakes. J Am Diet Assoc 110, 12 Suppl., S27-S37.

40. Sandström B (1989) Dietary pattern and zinc supply. In Zinc in Human Biology, pp. 350-363 [CF Mills, editor]. London: Springer-Verlag

41. MacFarlane AJ, Shi Y \& Greene-Finestone LS (2014) High-dose compared with low-dose vitamin B-12 supplement use is not associated with higher vitamin B-12 status in children, adolescents, and older adults. J Nutr $\mathbf{1 4 4}$, 915-920.

42. Pawlak R, Parrott SJ, Raj S et al. (2013) How prevalent is vitamin B(12) deficiency among vegetarians? Nutr Rev $\mathbf{7 1}$, 110-117.

43. Scientfic Advisory Committee on Nutrition (2010) Iron and Health. London: TSO.

44. Kromhout D, Menotti A, Kesteloot H et al. (2002) Prevention of coronary heart disease by diet and lifestyle: evidence from prospective cross-cultural, cohort, and intervention studies. Circulation 105, 893-898.

45. Geissler C \& Powers H (2005) Human Nutrition. London: Elsevier Churchill Livingstone.

46. Gingras D \& Beliveau R (2011) Colorectal cancer prevention through dietary and lifestyle modifications. Cancer Microenviron 4, 133-139.

47. Meier $\mathrm{T}$ \& Christen $\mathrm{O}$ (2013) Environmental impacts of dietary recommendations and dietary styles: Germany as an example. Environ Sci Technol 47, 877-888.

48. Temme EHM, Toxopeus IB, Kramer GF et al. (2014) Greenhouse gas emission of diets in the Netherlands and associations with food, energy and macronutrient intakes. Public Health Nutr (Epublication ahead of print version). 
49. Temme EHM, van der Voet H, Thissen JT et al. (2013) Replacement of meat and dairy by plant-derived foods: estimated effects on land use, iron and SFA intakes in young Dutch adult females. Public Health Nutr 16, 1900-1907.

50. Vieux F, Soler LG, Touazi D et al. (2013) High nutritional quality is not associated with low greenhouse gas emissions in self-selected diets of French adults. Am J Clin Nutr 97, 569-583.

51. Birch LL \& Fisher JO (1998) Development of eating behaviors among children and adolescents. Pediatrics 101, 539-549.
52. Gezondheidsraad (2011) Richtlijnen goede voeding ecologisch belicht. The Hague: Health Council of the Netherlands.

53. Macdiarmid J, Kyle J, Horgan G et al. (2011) Livewell: A Balance of Healthy and Sustainable Food Choices. UK: WWF and Rowett Institute.

54. Dagevos H, Voordouw J, van Hoeven L et al. (2012) Vlees vooral(snog) vanzelfsprekend. Consumenten over vlees eten en vleesminderen. Den Haag: LEI Wageningen UR.

55. Westhoek H, Rood T, van de Berg M et al. (2011) The Protein Puzzle. The Hague: PBL Netherlands Environmental Assessment Agency. 